\title{
The Gentleman of Birth: Oliver Twist
}

\author{
PhD. Mahmut Terci \\ Faculty of Philology and Education Sciences, \\ Department of English Language and Literature, \\ Bedër University, Tirana, Albania
}

\begin{abstract}
As the focus in this article is mainly on Dickens's descriptions of the gentleman of birth in Oliver Twist, selected extracts from the novel as well as critics' opinions will help us analyze the gentlemanly attitudes of the main characters connected to their noble origin and gentle manners. While Oliver opens his eyes in poor conditions, he always feels that he has noble blood. Dickens believes that manners not social status make people true gentlemen yet, he mixes the 'noble origin' issue in his novel Oliver Twist, probably as a result of the Victorian people's perception of 'gentility' which was very close to the concept of 'nobility'. Since Dickens added the flavor of 'noble' birth, his naïve nature as well as his perceptions - the way how he interprets people's behavior and things which happen around him and which construct his identity, his pure heart and his fate (reference to his belief and sincere praying) remarkably influence the positive changes in his life time. Dickens's little hero, Oliver Twist, while naturally appreciating goodness, is disgusted by immoral things like 'stealing,' which was unfortunately happening around. What are the main factors that shape his kind, noble and naïve character? Is it 'nature' or 'nurture'? What could be the major reasons for Nancy, Rose and Mr. Brownlow to give their assistance to Oliver? Whose -Mr. Brownlow's or Fagin's- teachings or influences are welcomed by Oliver? The answers to these questions will eventually illustrate how gentlemanly manners are inherited or acquired by Oliver.
\end{abstract}

Keywords: Charles Dickens, Oliver Twist, Victorian gentleman, nobility, gentility, wicked gentleman, true gentleman, gentleman of birth

\section{Introduction}

Childhood is the highly crucial period of time in the formation of gentlemanly manners and behaviors in one's life. In Oliver Twist Dickens portrays the main character, Oliver, who is born 'noble' and, thus, inherits this 'noble quality' from his parents. Whatever the circumstances he is pushed into later in his life, he manages to get rid of wrong doings. A young child, Oliver, finds himself without any parental support in the society is treated cruelly and instead of being pitied, he is hated and scorned. He is twisted with the merciless, heartless and brutal incidents.

It cannot be expected that this system of farming would produce any very extraordinary or luxuriant crop. Oliver Twist's ninth birthday found him a pale thin child, somewhat diminutive in stature, and decidedly small in circumference. But nature or inheritance had implanted a good sturdy spirit in Oliver's breast. $(O T, 9)$

Dickens suggests that Oliver's spirit will be good and strong due to his nature and inheritance even though all the troubles and difficulties will be very hard for a little boy. Critics, such as Cates Baldridge, claim that it is not so realistic that a child raised in poor conditions and later living with the criminals would be innocent and manage to be away from pick pocketing or stealing. To me, Dickens implies that difficult times, hard work, or harsh conditions force people to struggle more, to endure more, and to learn better how to survive in life. It is a biological or natural fact that viruses improve the immune 
system in a healthy body. And it is a pedagogical and sociological fact that the hardships make people's characters and personalities stronger. As to the inheritance, Oliver's little body could be biologically healthy and strong due to the immune system he inherited from his parents; a noble character cannot be inherited. The people -parents, relatives, neighbors, teachers- who are around us psychologically and pedagogically have great influences and effects on us so that our characters are shaped in that environment. The effect of 'inheritance' is also added to Oliver's formation of the character by Dickens so that the negative of his 'nurturing' could be ignored and his 'kind' behavior and 'gentle' manner could be explained.

\section{Nurture or Nature?}

Cates Baldridge mentions this issue in his article entitled "The Instabilities of Inheritance in Oliver Twist". He argues that

"Nurture" cannot explain Oliver's character since he was nurtured in the workhouse; "nature" - in the sense of a physical and moral inheritance - becomes the only explanation we can reasonably consider once we begin to discover the identities of the hero's parents. Oliver physically resembles his progenitors, and the unmistakable implication of his likeness to Brownlow's pictures and memories is that his middle-class personality comes from the same source. (Baldrige, 186)

Partly, I agree with Baldridge in terms of Oliver's unchanged character that any bad environment cannot affect him in a negative way. $\mathrm{He}$ is protected and helped unexpectedly within many coincidences in the story. First Rose and then Mr. Brownlow and even Nancy gave assistance to Oliver and are some examples that might rarely happen in the real life. Moreover, it is quite difficult to find this sort of people who can protect themselves from evil doings despite that fact that they live with wicked people. It is almost impossible for such an unprotected small orphan child like Oliver who lives among professional criminals to be away from evil, i.e. Fagin's teachings. It is true that the chance to see such selected or protected people is too low in the normal life, but even a small possibility should be taken into the consideration so that various people in the society should behave how they are supposed to do. And it is also true that it is not a common thing to meet this kind of characters, but there is always a possibility that people in such hard conditions could save themselves or could be saved by benevolent, gentle and generous people. Dickens creates a kind of child hero who could be a good example for the other children facing a lot of difficulties in their childhood without parental support. There might be a difficult period for anybody to endure so that the result of the patience in these hard times might be very fruitful. While Dickens attracts the public attention to the poor conditions in the workhouses and implies that the government should pass some certain laws to improve the conditions and standards of the people in these public places, namely parishes, he also gives a special emphasis to the benevolent gentlemen who are ready to help these poor orphans who really need sincere love, close care and generous assistance during their hard times while growing up.

Is 'nature' or 'noble blood' the explanation of Oliver's ideally kind character? Why does not Monk, Oliver's half-brother, have kind and noble attitudes like him? And how come the two brothers are the opposite of each other? The same thing may be observed in Nicholas Nickleby; while Ralph Nickleby is so mean, cruel and rude, it is assumed that his brother or Nicholas's father is probably a true gentleman as nothing bad about him is mentioned in the novel. So, we could argue that 'nature' itself in the sense of physical and moral inheritance could not be the single explanation of their gentlemanly manners. Not only these two cases in Dickens's novels, but also examples from real life, even today, the brothers and sisters who are 'nurtured' by the same family and even in the same schools could be different from one another. Why? Because everybody is born with certain qualities such as 'pure heart', 'pure mind', 'will power', 'physical inheritance'. Yet, it is the person himself who decides to learn or acquire bad or evil deeds. Whatever the surroundings they live in, it is each person's 'free will' of what to do, what to learn, how to live, and how to behave in life. The education given in the family and at school, and the moral values one gets in his culture; they all have some effects on people. But people's own 'truths' or their own 'choices' of what to do and how to behave shape each person's character.

According to Aristotle, "educating the mind without educating the heart is no education at all."1 It is really crucial for a gentleman to keep his heart pure or to educate it if he is to be considered a true gentleman. As long as a person tries to keep himself away from all evil deeds, such as gossiping, lying, slandering, stealing, killing, torturing, insulting, robbing,

\footnotetext{
${ }^{1}$ See http://www.quoteswave.com/picture-quotes/240986
} 
or any kind of evil deeds or crimes, he/she does not harm directly the others physically or psychologically. Unfortunately, many hearts are blackened with the crimes and mischievous behaviors. Thomas Taaffe uses of the term 'heart' with various nuances as follows:

Our hearts may be glad or sad, troubled, aching, or sick. They may be heavy or light, warm or cool, cruel or kind. Our hearts may be aflame with love, or broken. To have a heart is to be empathetic, to have no heart is to lack feeling; and we pray to change our hearts of stone into hearts of flesh and blood. This sense of "heart" as the center of feeling includes its place as access to the other. We open our hearts, or close our hearts. We hold another in our heart; or reach for another in heart-to-heart communication. Hearts speak to hearts. Two hearts may beat as one; indeed, a whole community may act with one heart. The general association of "heart" with affectivity is clear enough, but even in ordinary usage there are further important nuances to this rich word. (Taaffe, 380)

In order to keep the heart pure and to make gentlemanly behavior permanent in one's character, it is essential to know human nature with its strengths and weaknesses. How can one keep the heart pure, then?

Dickens, who exposed the harsh reality of the Industrial Revolution, has direct and indirect contributions in discussing the gentlemanly behavior with the Victorian readers. He sympathized with the plight of the underprivileged; mainly the poor, children and women, and he sought to raise awareness in the Victorian society. The injustice and unbearable living conditions experienced by the people probably touched his heart so that he used these facts and reflected them in his works. He was not only an author, but also a social activist who used to raise awareness through his works, social charities and public speeches to bring social reforms in his time. In her study, Pamela Makati states that:

His works were a form of direct appeal to society to take action against poverty, exploitation of children and the oppression of women. Apart from writing novels as a form of fuelling social change, Dickens was also actively involved in charities which funded schools for the poor and also reformation institutions for prostitutes. His essay writing and the delivery of speeches also acted as vehicles for social change. Therefore, this research ultimately seeks to proclaim that Dickens was not just a fiction writer, but his works had a social mission, to make the readers take note of the unprivileged members of the Victorian society so that they could take action to improve their plight. (Makati, 4)

Makati also claims that realism is often concerned with the highlighting the need to create a morally upright society. And she backgrounds this premise to John Peck and Martin Coyle who propose that "realist novelists are often moralists, concerned with how correct conduct can be achieved in the complex conditions of the real worlds" (39) Dickens, therefore, ventures into social realms and deals with subclasses of humanity. In the preface to Oliver Twist, Dickens explains why he has written this novel as follows:

It appeared to me that to draw a knot of such associates in crime as really do exist; to paint them in all their deformity, in all their wretchedness, in all the squalid poverty of their lives; to show them as they really are, for ever sulking uneasily through the dirtiest paths of life, with the great, black, ghastly gallows closing up their prospect, turn them where they may; it appeared to me that to do this, would be to attempt a something which was greatly needed, and which would be a service to society. (Oliver Twist, xii)

The detailed descriptions of the wretchedness, poverty, dirtiest paths of life are used to terrify the ordinary people for the sake of goodness and a crime-free society. Especially in Oliver Twist Dickens portrays the miserable lives of orphans, poor children and women who lived in parishes and he makes a connection between the boosting of crimes and the poor conditions these people have overcome. In this way, he does not only increase the public awareness about the sources of the crimes, but he also provokes the government to pass needed laws for the workhouses. At this point, it has to be mentioned that Dickens's attacks on the old Poor Law through this novel had some influences on the parliament. Sirinya Pakditawan points out this fact as follows:

The Poor Law of 1834 wanted to make the workhouse more a deterrent to idleness as it was believed that people were poor because they were lazy and needed to be punished. So people in the workhouses were deliberately treated harshly and the workhouses were similar to prisons. Nonetheless, the plan was successful from one point of view, for within three years the cost of poor relief was reduced by more than one-third. However, this system was sharply criticized and 
censured: Dickens, for instance, attempted to improve the workhouse conditions with his novel Oliver Twist and as a result, this work helped influence changes in the problem. (Pakditawan, 4)

Hence, this novel could also be considered as an example which had positively influenced the members of the parliament to pass laws so that the conditions in workhouses were improved. Dickens himself suffered the hard times caused by the English legal system and used his own experience in his works. Thus, in Oliver Twist Charles Dickens describes the life of Oliver, whose hardships begin as soon as he is born:

Although I am not disposed to maintain that the being born in a workhouse, is in itself the most fortunate and enviable circumstance that can possibly befall a human being, I do mean to say that in this particular instance, it was the best thing for Oliver Twist that could by possibility have occurred. (Oliver Twist, 4)

However, paradoxically, being born in a workhouse is described to be "the most fortunate and enviable circumstance that can possibly befall a human being". First of all, his mother was very sick and she was coming from a long way that nobody knew who she was and where she was going. Fortunately, she found herself near people who could help her during delivery. Second, if she had died before giving birth, Oliver would not have survived. While portraying a very sad moment for Oliver (losing his mother), Dickens leads readers to an optimistic vision, by implying that the character will have better conditions later in his life. As it can be guessed from the family name which was chosen for the main character, the burdens, hardship and the unbearable circumstances 'twist' Oliver all his life. Obviously, Dickens aims at provoking the good, gentle and merciful side of those who witness the people living in those wretched houses. The Victorian society had lots of problems such as child labor, poverty, unemployment, all sorts of crimes and absence of laws. Dickens describes the terrible and miserable conditions for a new-born baby who is not aware of anything, as follows:

What an excellent example of the power of dress, young Oliver Twist was! Wrapped in the blanket which had hitherto formed his only covering, he might have been the child of a nobleman or a beggar; it would have been hard for the haughtiest stranger to have assigned him his proper station in society. But now that he was enveloped in the old calico robes which had grown yellow in the same service, he was badged and ticketed, and fell into his place at once--a parish child--the orphan of a workhouse--the humble, half-starved drudge--to be cuffed and buffeted through the world--despised by all, and pitied by none. (Oliver Twist, 6 )

With this description, Dickens sets the tone of the events in Oliver's later life. Sadness symbolized by the color yellow which will be his harsh experience at the workhouse, at the undertaker's house and in London. 'A parish child', 'the orphan of a workhouse', 'humble and half-starved drudge', 'cuffed and buffeted' and 'despised by all but pitied by none' are the combinations of the words skillfully chosen to make the readers get the clear picture of Oliver Twist's conditions. When Oliver is nine, he is demanded to work like an adult. It becomes quite hard for Oliver to go for a work at this age and this becomes his second difficult stage in his life.

This was no very great consolation to the child. Young as he was, however, he had sense enough to make a feint of feeling great regret at going away. It was no very difficult matter for the boy to call tears into his eyes. Hunger and recent ill-usage are great assistants if you want to cry; and Oliver cried very naturally indeed. (Oliver Twist, 12)

This age was considered the proper time to work in the workhouses at that time. The Industrial Revolution was the time when there were very limited opportunities for children. Children had to work under terrible conditions and were paid less than adults. For example, John Robert Clynes, who used to be a politician working in the House of Commons a couple of times, was ten in 1879 when he worked as a 'piecer' and was employed in spinning mills to tie broken threads in textile factories. He describes the hard conditions which the children suffered as follows:

When I achieved the manly age of ten I obtained half-time employment at Dowry Mill as a "little piecer." My hours were from six in the morning each day to noon; then a brief time off for dinner; then on to school for the afternoons; and I was to receive half a crown a week in return. ... I remember no golden summers, no triumphs at games and sports, no tramps through dark woods or over shadow-racing hills. Only meals at which there never seemed to be enough food, dreary 
journeys through smoke-fouled streets, in mornings when I nodded with tiredness and in evenings when my legs trembled under me from exhaustion. ${ }^{1}$

There were many other children such as William Dodd, Angus Reach and Frances Trollope in real life who worked in those hard times, who prayed that the Lord would take them to himself before the next morning. Dickens ironically describes the board members of the workhouse as "fat gentlemen":

Not having a very clearly defined notion of what a live board was, Oliver was rather astounded by this intelligence, and was not quite certain whether he ought to laugh or cry. He had no time to think about the matter, however; for Mr. Bumble gave him a tap on the head, with his cane, to wake him up: and another on the back to make him lively: and bidding him to follow, conducted him into a large white-washed room, where eight or ten fat gentlemen were sitting round a table. At the top of the table, seated in an arm-chair rather higher than the rest, was a particularly fat gentleman with a very round, red face. (Oliver Twist, 12)

The readers notice that on the one hand, there are skinny children who have been harmed physically, mentally, morally and deprived from a proper education, but on the other hand there are 'fat-gentlemen' who never care for them and think only of their own selfish benefits. The 'fat-gentlemen' never attempt to work; what they really know best is just to sit lazily, eat gluttonously and make bulgy bellies. That is why they are stereotypically portrayed as fat with red faces:

'Boy,' said the gentleman in the high chair, 'listen to me. You know you're an orphan, I suppose?'

'What's that, sir?' inquired poor Oliver.

'The boy is a fool--I thought he was,' said the gentleman in the white waistcoat.

'Hush!' said the gentleman who had spoken first. 'You know you've got no father or mother, and that you were brought up by the parish, don't you?'

'Yes, sir,' replied Oliver, weeping bitterly.

'What are you crying for?' inquired the gentleman in the white waistcoat.

And to be sure it was very extraordinary. What could the boy be crying for? (Oliver Twist, 14)

Dickens portrays the fat gentlemen as ignorant, shameless, insensible and insensitive, so that the readers may easily see that they do not have any pedagogical expertise of how to treat a small child, especially a parentless sensitive child. Dickens pinpoints the fact that it is surely an extraordinary case for these people and he invites us to think "what the boy could be crying for." As Walter Allen explains in his book Six Great Novelists, "it is the abandoned child's cry of anguish at the inhumanity which he is subjected, scorched and orchestrated by a composer genius and the child's cry becomes the arraignment of the age."(W.Allen in Srivastava, 32)

Oliver is chosen by his friends to ask a question. They cannot dare to ask because they already know how children are punished for being inquisitive. But they are so hungry that they want to use an alternative way to convince their master that they would like more food:

Child as he was, he was desperate with hunger, and reckless with misery. He rose from the table; and advancing to the master, basin and spoon in hand, said: somewhat alarmed at his own temerity: 'Please, sir, I want some more.'

The master was a fat, healthy man; but he turned very pale. He gazed in stupefied astonishment on the small rebel for some seconds, and then clung for support to the copper. The assistants were paralyzed with wonder; the boys with fear.

\footnotetext{
1 See Piecers in the Textile Industry http://www.spartacus.schoolnet.co.uk/TUclynes.htm
} 
'What!' said the master at length, in a faint voice?

'Please, sir,' replied Oliver, 'I want some more.'...

'That boy will be hung,' said the gentleman in the white waistcoat. 'I know that boy will be hung.' (Oliver Twist, 17)

They know that the ones who ask for more are hung as a punishment. It is decided that Oliver's name has to be hung as an announcement! A notice or a kind of flyer is hung for any volunteer who wishes to look after him. It is amazingly remarkable how the 'fat', 'healthy' and 'red-faced' men turned pale, paralyzed and astonished with an innocent demand. Sending away or getting rid of these poor people was the policy of the boards in the parishes because more people meant more expenses for them. When compared with the total population (one million) who lived in London ${ }^{1}$, the historian Ben Wilson points out the number of the parishes in 1800 s as follows:

The oldest areas lay under the administration of the Common Council of the City: the Square Mile (population 58,400) and sixteen parishes $(72,000)$ lying outside the City walls but within its jurisdiction...A further five parishes -such as Marylebone and St.Pancras- lay outside London's ancient boundaries, but were still part of the metropolis, connected by an interrupted succession of houses; 224,300 people lived in these parishes. (Wilson, 248-9)

Wilson, in fact, states these numbers to show that the number of the police assigned to patrol the different areas in London, was not sufficient to prevent the crimes in those years. From the figures we clearly see that there were many poor people to take care of. This might be one of the other reasons why the children were sent away as soon as any volunteer was found. It was not a great matter for the 'fat members' of the board whether the children are sent away for hard work or not.

\section{The 'Gentleman' in the White Waistcoat}

From a different perspective, John R. Reed focuses his attention to the gentleman in the white waistcoat in his essay The Gentleman in the White Waistcoat: Dickens and Metonymy. He claims that "he might be an intensifier, since Dickens not only endorses the board's treatment of Oliver but seems to relish it with sadistic enjoyment." (Reed, 413) Leaving the detailed analysis to the chapter "The Wicked, Devious Gentleman", we should note that the unkind and insulting manners applied in one's attitude not only attract other people's hatred which might cause counter uncontrollable outbursts, but also they cut off mutual understanding and dialogue.

It is also claimed that Dickens wrote Oliver Twist just after three years the Poor Law Amendment Act 1834, because he was strongly against this act and this provoked his angry memories of his deprivation, of his separation from his family and his own obsessive comparison of the need for food with the need for love. Nevertheless, L.Smith ${ }^{2}$, S.J. Thorton ${ }^{3}$ A.N William ${ }^{4}$ agree that Dickens's novel is a timeless chronicle of abused childhood. Its strength and vigor still reminds people today of those who are disadvantaged and outside of society. And they conclude their views with the fact that Dickens's fictional 'truth' does not always coincide with the facts.

On the contrary, as Dr. P. O Brennan from Sheffield Children's Hospital in UK mentioned in her article entitled "Oliver Twist: Textbook of Child Abuse" ${ }^{5}$, what might have been acceptable in Victorian England was not acceptable with Dickens, who expresses his disapproval of this situation. According to the childcare standards in Britain in the year 2001, much of the childcare described in Oliver Twist constitutes child abuse. The examples are listed from Oliver's mother's death in childbirth attended by a drunken 'midwife' and an uncaring doctor to the children neglected, barely fed or clothed in baby farms and later in the workhouses; from children's emotionally abused, being deprived of all human adult love or affection to the punishments as being locked in a small dark room 'after asking for more'; from physical abuse to the sequel abuse,

\footnotetext{
1 See http://www.oldbaileyonline.org/static/London-life19th.jsp

2 Dietetic assistant Department of Dietetics, Northampton General Hospital, Northampton. NN1 5BD

${ }^{3}$ Senior pediatric dietician Centre for the History of Medicine, Medical School Birmingham, Birmingham B15 2TT

4 Consultant Community Pediatrician, Virtual Academic Unit, CDC, Northampton General Hospital, Northampton NN1 5BD

5 Dr. P. O Brennan Oliver Twist, textbook of child abuse Arch Dis Child 2001;85:504-505 doi:10.1136/adc.85.6.504
} 
including absconding, passivity, 'stupidity', depression, poor self image, and vulnerability to corruption by anyone who seems to show them some love or attention; and from sexual abuse, vaguely referred to in descriptions of Nancy and Betsy, the prostitutes to substance abuse, in the form of alcohol abuse like Bill Sikes who drank alcohol at almost every appearance.

From the examples mentioned above, how people, especially the weak ones like children, behaved, had a deep impact on their characters. Psychological and pedagogical refined approaches to children have much more importance to create gentle manners in their behavior. There were many poor and unemployed people at that time.

Oliver fell on his knees, and clasping his hands together, prayed that they would order him back to the dark room--that they would starve him--beat him-- kill him if they pleased--rather than send him away with that dreadful man. (Oliver Twist, 27)

Somehow Oliver's sincere facial expressions and touching begging impress the board and they give up the idea of sending him away with that dreadful man. Luckily, Oliver's destination from the workhouse is postponed for a few days. But he is on the black list and sooner or later he is to leave the workhouse.

When little Oliver was taken before 'the gentlemen' that evening; and informed that he was to go, that night, as general house-lad to a coffin-maker's; and that if he complained of his situation, or ever came back to the parish again, he would be sent to sea, there to be drowned, or knocked on the head, as the case might be, he evinced so little emotion, that they by common consent pronounced him a hardened young rascal, and ordered Mr. Bumble to remove him forthwith...The simple fact was that Oliver, instead of possessing too little feeling, possessed rather too much; and was in a fair way of being reduced, for life, to a state of brutal stupidity and sullenness by the ill usage he had received. He heard the news of his destination, in perfect silence; and, having had his luggage put into his hand--which was not very difficult to carry, inasmuch as it was all comprised within the limits of a brown paper parcel, about half a foot square by three inches deep-he pulled his cap over his eyes; and once more attaching himself to Mr. Bumble's coat cuff, was led away by that dignitary to a new scene of suffering. (Oliver Twist, 32)

The bolded words are used to draw the attention on how these 'gentlemen' behave to a young boy. Oliver is threatened severely, abused emotionally, scorned heavily and treated sullenly. The term 'gentlemen' is in quotation marks for the reason that Dickens implies its opposite meaning. It is almost impossible to make this kind of 'gentlemen' aware that other people are also human. Unfortunately, their feelings and thoughts are so badly deformed that the terms virtue, goodness, grace and merit do not make any sense for them at all. As Dickens uses the term 'gentleman' in quotation marks, he makes the readers think if these gentlemen are true or fake.

Mr. Sowerberry, the coffin-maker and a friend of Mr. Bumble the beadle, takes Oliver from the parish to use of him for his own work. On the way, Oliver starts crying again leaving all the acquaintances behind whilst getting into a new scene of suffering.

\section{'So what?' inquired Mr. Bumble in amazement?}

'So lonely, sir! So very lonely!' cried the child. 'Everybody hates me. Oh! sir, don't, don't pray be cross to me!' The child beat his hand upon his heart; and looked in his companion's face, with tears of real agony. (Oliver Twist, 34)

It is human nature that people prefer living, travelling, talking and sharing their lives with other people. Socializing is one of the crucial needs of human beings. In addition, 'loneliness' for an orphan being deprived of parental love is much more a sensitive case. In another place, Dickens emphasizes a similar impression when Oliver is shot and abandoned in the middle of a remote countryside. At that time, he was with the criminals who captured him and forced him to steal with them and he was trying to escape from the people whose house he attempted to burglarize.

He looked about, and saw that at no great distance there was a house, which perhaps he could reach. Pitying his condition, they might have compassion on him; and if they did not, it would be better, he thought, to die near human beings, than in 
the lonely open fields. He summoned up all his strength for one last trial, and bent his faltering steps towards it. (Oliver Twist, 264)

With these descriptions, Dickens aims at creating a hopeful atmosphere that not all the humans are as bad as he had described by then. There are some generous, benevolent, gentle, and caring people as well in this world.

In his new 'home', Oliver is shown his bed which is located under the coffin counter. Why did not the Sowerberrys show Oliver a better place? Dickens invites us to think of a little child's psychology that was forced to sleep among the coffins. Sometimes, the gloomy atmosphere confines us on every side and we feel that death is much better than being alive. In such dreadful situations, one should have patience, courage, and determination that every winter is followed by spring and every dark night is followed by a bright and sunny day. Therefore, Dickens sets a similar hopeful atmosphere for Oliver and the readers are led to think of the death which could be better for him. Actually, Mr. Sowerberry's occupation has a close relationship with death. Dickens gives a clue for the readers choosing an eccentric name for these people, as the term 'sower' is the homophone of the word 'sour'. While people enjoy eating 'strawberry' as they have delicious taste, they most probably dislike the 'sour-berry'. Dickens criticizes people like the 'Sowerberrys' by giving them names with certain significance.

Oliver meets Mr. and Mrs. Sowerberry, the serving girl Charlotte and Noah Claypole who is the other high ranker boy working for this family. Dickens again gives some clues about his mean character from his family name. While the term 'clay' implies dirtiness, impureness, filthiness and mess, the term 'pole' implies that Oliver and Noah have completely opposite personalities.

It shows us what a beautiful thing human nature may be made to be; and how impartially the same amiable qualities are developed in the finest lord and the dirtiest charity-boy. (Oliver Twist, 40)

Dickens takes the readers' attention to Noah's background and then he especially focuses on the human nature. Although the boys are impartially in the similar conditions, the qualities, the personalities they will turn into in the future, will be different. The lived hardships for the finest lord type (reference to Oliver) and for the dirtiest charity-boy (reference to Noah) will grow and have opposite impacts on them. Similar to goodness or disasters, the life's ups and downs, usually have different effects on people and things according to the strengths and weaknesses which they encounter. We will be involved in many events and cases and will have experiences in this life. There will be inputs and outputs. Nevertheless, all the inputs and outputs will be different from one another. Therefore, Dickens implies here that Oliver's 'noble' background has some effects on his 'naïve' and 'honorable' character containing the features of a true gentleman's nature.

'There's an expression of melancholy in his face, my dear,' resumed Mr. Sowerberry, 'which is very interesting. He would make a delightful mute, my love.' (Oliver Twist, 41)

The unbearable sufferings which have drawn melancholic features on Oliver's face mean something else for Mr. Sowerberry. Whereas he might have shared Oliver's heart-breaking grief and be helpful as much as he could, his hardened heart has never had any mercy for the others. Selfishness, ignorance and callousness make the eyes blind at other people's sufferings. Another weakness or illness in human nature, which a true gentleman should stay away from, is jealousy. Noah's jealousy rises when Oliver is promoted by Mr. Sowerberry to another job due to his natural melancholy that works better in funerals. Noah's ill-treatments get worse each day as a result of this jealousy.

That Oliver Twist was moved to resignation by the example of these good people, I cannot, although I am his biographer, undertake to affirm with any degree of confidence; but I can most distinctly say, that for many months he continued meekly to submit to the domination and ill-treatment of Noah Claypole: who used him far worse than before, now that his jealousy was roused by seeing the new boy promoted to the black stick and hatband, while he, the old one, remained stationary in the muffin-cap and leathers. (Oliver Twist, 50)

Dickens describes a very important turning point about Oliver's life at this stage. 
And now, I come to a very important passage in Oliver's history; for I have to record an act, slight and unimportant perhaps in appearance, but which indirectly produced a material change in all his future prospects and proceedings. (Oliver Twist, 50)

Thus, fighting for honor plays an important role in human nature and the positive results will be mentioned shortly afterwards.

Crimson with fury, Oliver started up; overthrew the chair and table; seized Noah by the throat; shook him, in the violence of his rage, till his teeth chattered in his head; and collecting his hole force into one heavy blow, felled him to the ground. A minute ago, the boy had looked the quiet child, mild, dejected creature that harsh treatment had made him. But his spirit was roused at last; the cruel insult to his dead mother had set his blood on fire. His breast heaved; his attitude was erect; his eye bright and vivid; his whole person changed, as he stood glaring over the cowardly tormentor who now lay crouching at his feet; and defied him with an energy he had never known before. (Oliver Twist, 52)

Since his mother is a very sensitive subject to him, Oliver becomes really furious. Noah continues to taunt him and insults his mother until Oliver attacks him. Oliver, who used to be naïve and calm until then, cannot stop fighting the boy who verbally attacks his mother. We may argue that this is another important 'noble' feature of character: fighting for the honor, which is portrayed by Dickens to show another quality of the gentleman, reminiscent, perhaps of the knightly code. Despite the fact that Dickens is against dueling, he uses fighting to recover the character's honor from time to time in his novels. For instance, in order to save the miserable boy, Smike, from the mercilessly beating hands of Mr. Squeers, Nicholas Nickleby stops his beating and then gives him physical punishment which might be more effective. Therefore, it could be deduced that Dickens agrees to give punishments to the villains when they cross limits. He uses this kind of violence when it is meant to stop tyranny, cruelty or oppression.

'Meat, ma'am, meat,' replied Bumble, with stern emphasis. 'You've over-fed him, ma'am. You've raised a artificial soul and spirit in him, ma'am unbecoming a person of his condition: as the board, Mrs. Sowerberry, who are practical philosophers, will tell you. What have paupers to do with soul or spirit? It's quite enough that we let 'em have live bodies. If you had kept the boy on gruel, ma'am, this would never have happened.' (Oliver Twist, 58)

The outrage against Noah is wrongly interpreted by Mr. Bumble, who is the representative of the unfair system, as the effect of consuming meat. According to these 'gentlemen', giving meat to children is a great mistake! They should be been given gruel only! As they believe that, a kind of luxury like meat, cause to raise an artificial soul in them! The unfair system makers and its parasites have always considered the weak and the poor as second-class citizens. Dickens's purpose in describing these atrocious conditions was both to reveal the reality behind the industrial façade of the British economic system and to create a melodramatic scene which would increase the number of readers. The fat gentleman and the gentleman in the white waistcoat are meant to caricature portraits of what may wrongly be named gentlemanly behavior. They are the characters set in opposition to the requirements of the ideal portrait of the gentleman, as envisaged by Dickens and offered to the Victorian readers as a goal to attain.

\section{The Making of a Gentleman}

Counted alongside George Meredith and Thomas Hardy as one of the best three novelists of the turn of the century, George Gissing writes about Dickens's political views that, like other men of letters, Dickens was very much concerned about social questions. Therefore,

he imagined that the columns of a great newspaper would afford him the best possible field for making known his views and influencing the world. One step which has tempted writers from their appointed task he seems never to have seriously contemplated; he received invitations to stand as a Parliamentary candidate, but gave no ear to them. The term which described him as politician and social reformer is no longer in common use; he was a Radical. (Gissing, 66)

Through Gissing's view it could be concluded that Dickens, who brought forward the miserable and harsh conditions of the poor children by writing the novel Oliver Twist, did not show any tendency to be a politician to solve social problems and he never claimed that he was a social reformer. According to Gissing, it could probably have been quite easy for 
Dickens to become a member of the Parliament if he really desired and attempted to use his fame and popularity. However, Dickens's preference for writing, instead of getting involved in politics, is considered as 'radical choice' by Gissing so that he describes him as a 'Radical' man rather than a 'politician' or a 'social reformer'. Dickens's main concern was to serve the society willing to see everybody taking a part in solving the socially unfair and unjust regulations or laws and their application to the underprivileged and the poor. Thus, to Dickens gentility could be inherited, but it could also be obtained through education, which, we may argue, was of two kinds: street education and school education. This is what also awaits Oliver in his life journey and growth into a real gentleman.

After his fight with Noah and the punishment, Oliver makes up his mind to flee to search of new opportunities in London. Hoping to meet kind people and get better conditions, he runs away. Dickens uses this fictional trick, sending the main or important characters to other towns or countries (namely to London and Australia), in the hope of getting better conditions of life and job opportunities, to reflect the positive thinking and the dreams of the Victorian people. On the way to London, he meets a 'good-hearted' turnpike-man and a 'benevolent' old lady who voluntarily help Oliver, in spite of their own poverty. The kind behavior, which has a 'deep impact' on the protagonist, is praised by Dickens as follows:

In fact, if it had not been for a good-hearted turnpike-man, and a benevolent old lady, Oliver's troubles would have been shortened by the very same process which had put an end to his mother's; in other words, he would most assuredly have fallen dead upon the king's highway. But the turnpike-man gave him a meal of bread and cheese; and the old lady, who had a shipwrecked grandson wandering barefoot in some distant part of the earth, took pity upon the poor orphan, and gave him what little she could afford--and more--with such kind and gentle words, and such tears of sympathy and compassion, that they sank deeper into Oliver's soul, than all the sufferings he had ever undergone. (Oliver Twist, 65)

Although the old lady has very little food, she shares it with Oliver. Especially her kind and gentle words with sympathy and compassion affects Oliver deeply. He forgets all his suffering and the way that she approaches him feeds his soul. In other words, kind and gentle words have deep influences on his 'noble' character. Dickens gives a special emphasis on how a very little help with the 'kind' and 'gentle' words transferred into 'sympathetic ' and 'compassionate' mood could give positive energy to a child and how this kind of attitude may shape one's character and develop 'kind' and 'gentle' manners.

According to Alfred Adler, a psychotherapist and founder of the school of individual psychology in the twentieth century, "the most important and the most valuable part of our existence is "inner life."' (Adler, 417) He explains this view as follows:

For in the life of a child and in his physical and mental growth, there is a largely hidden trend that leads "upwards," that unceasingly guides and regulates all the psychological realities mentioned above, thus placing them in its service: Instincts and reflexes are adjusted, recognized as "appropriate," modified and utilized; movement of eyes, limbs, and trunk respond to a "plan"; all emotions - pleasure, joy, grief, pain, anger, love, hate, desire - manifest themselves at appropriate occasions, and by the manner and the degree in which they are expressed, they establish close contact with the environment and with the people in their immediate surroundings. There also soon appear traces of character traits, like call and response to the demands of the environment, represent a further connection to the outside world. (Adler, 417)

Adler pinpoints the formation of a child's manners with the faculties of his 'inner life' and his surroundings 'outside world'. Whether people are aware or not, children who record all kinds of behaviors and manners they come across within the social life record or codify them on their minds. Then, they behave according to the recordings which they acquired unintentionally or naturally before. Mr. Brownlow's and Rose's continuous kind, benevolent and generous behavior that Oliver experiences later in the story has a deep impact on his character. Even Nancy's desperate attempt to save Oliver from Sike's severe punishment has a deep influence on his manners. Since it is not quite an extraordinary behavior to see goodness from a kind person, but it is extraordinarily remarkable to see that a dood deed is performed by an evil, sinful character. With this, Dickens aims at emphasizing a very significant human nature about the wicked characters that they are not always so bad. Since they are also human beings they might behave well because from time to time their compassionate and merciful sides - hidden in each individual's nature - might weigh more than their cruel and ruthless side. 
After a long and tiring journey, Oliver succeeds in reaching London with the help of Dodger whom he meets on his journey. Dodger invites him to the place where he loves. There he meets Fagin and the other boys and girls. He is shown a bed and offered some food. The next morning, the boys begin playing a game in which they practice picking Fagin's pockets without being noticed. Fagin asks Oliver if he would like to try the game. Oliver is praised with his great talent and in time he begins to learn how to 'unmark' silk handkerchiefs.

Oliver wondered what picking the old gentleman's pocket in play, had to do with his chances of being a great man. But, thinking that the Jew, being so much his senior, must know best, he followed him quietly to the table, and was soon deeply involved in his new study. (Oliver Twist, 79)

Fagin's teachings start with these games. 'Stealing' without 'being noticed' is systematically and professionally taught to little children in the den. They are taught in a play format so that children would enjoy these 'unofficial' lessons. Meanwhile, Oliver gets bored to stay at home alone when the other boys are out. He asks Fagin to go out with the other boys and finally he is allowed. On his first day out, Oliver realizes that the boys commit crimes and is shocked when he sees them stealing a gentleman's handkerchief. While the readers expect better opportunities for Oliver, Dickens, who also planned to show the 'dark' world of the criminals located in London, intentionally pushes his naïve protagonist to Fagin's den so that his readers may become aware of the various crimes in a city in which poverty reached a high percentage. Lynn Pykett describes the city as follows:

As experienced by Oliver the city is a maze, an 'infernal labyrinth', at the centre of which are Fagin and his criminal associates. (Pykett, 47)

The traps and webs are set by all sorts of criminals whose behavior resembles the spiders' or hunters' deadly waiting for their prey. The big cities have always been the centre of criminal conduct. Newcomers, especially children, might fall into these traps easily. As mentioned before, by Philip Collins, "crime was topical issues in his time" (Collins, 2) and Dickens gets the opportunity to point out the criminal gangs who appeared in the poor areas of London. In general, while Dickens makes the readers see how Fagin has created an illegal system in a big city, he also points out the weakness of this system and the need for proper education to turn the poor into peaceful members of the society. In The Making of Victorian Values, Ben Wilson reveals the large number of poor children going to Sunday schools, learning to read and more importantly learning good manners. He states that

On average a child who attended a school on Sunday and learned to read from the Bible might be tolerably literate within three years. The possibilities of better life were apparent enough to motivate children and parents. Employers such as shopkeepers and keepers of warehouses and who needed servants preferred to take on boys and girls with good manners and at least a rudimentary education. By no means all children went to a Sunday school, but the numbers were impressive; in London 35,460 poor children were taught each week by four thousand voluntary teachers. (Wilson, 268)

To prevent crime and built an educated and well-mannered society, the literate individuals (boys and girls) with good manners are offered jobs and a motivation to improve their economic and social position in life. Hungry and jobless people might get involved in crimes but especially uneducated and aimless people are potential criminals in the society. To be a gentleman, to behave like a gentleman and to be respected like a gentleman becomes an important goal in life, a social force for the lower and the middle class Victorian people. We therefore argue that Dickens's purpose in this novel is to stress not only the in-born noble nature of Oliver, but also the way in which a poor child may grow into a gentleman.

\section{Conclusion}

We have mentioned that, firstly, Dickens is a radical who wished to improve the conditions of underprivileged and ordinary people in the society and aimed at increasing awareness to social problems, especially to the crimes and criminal organizations that threatened thousands of lives. Instead of being a Member of Parliament and becoming a politician, Dickens prefers to write. Believing that the words that touch hearts have special powers on people, Dickens aims at influencing the minds and souls with his books that can contribute to the construction of a healthy society. Only the individuals whose moral faculties are enriched by useful knowledge, love, affection, kindness, respect, gentleness, goodness, and honesty can form such a society. Secondly, Dickens gives a special emphasis to the moral issues related 
to heart which forms the real dimension of a person. Thirdly, like people's strong social consciousness, their beliefs have great influences on the positives changes in human souls and in society. Fourthly, I oppose critics, like Castronovo, who think that a person just like Oliver Twist, is almost impossible to retain his goodness in an environment of crimes and evil deeds. It seems that it is not logical, but, on the other hand, there are many examples in history of such pure-hearted individuals disgusted of evil things. Millions of them were born, lived and even gave their lives just for an ideal.

With Oliver Twist Dickens chooses a sentimental way to touch the hearts of his readers with brutal incidents experienced by a pure-hearted child, draws the people's and the government's attention to the social problems in a metropolis and raises awareness of children's abuse and psychology. However, these are concrete paths to the rise of the gentleman, or at least to gentlemanly behavior, irrespective of the nobility of birth. Oliver may be seen as the first illustration of the gentleman of birth and manners in Dickens's fiction. Oliver's inborn qualities make him a gentleman, not his allegedly noble parents. In other words, Oliver becomes the image of the democratic gentleman, the person who goes through suffering but does not lose his pure heart, the essential characteristic of a gentleman's attitude towards the society. Oliver is the nineteenth-century Romantic kind of gentleman, whose ancestor seems to be the "very parfit" medieval knight, whom Chaucer describes.

\section{Bibliography}

\section{Primary Resource}

Dickens, Charles. Oliver Twist free eBooks at Planet eBook

http://www.planetebook.com/ebooks/Oliver-Twist.pdf

\section{Secondary Resources}

Adler, Alfred. Individual Psychology Vol.44, No.4, December 1988

Baldridge, Cates. The Instabilities of Inheritance in Oliver Twist - HighBeam Research Article. Published on 6/22/1993.

Castronovo, David. The English Gentleman: Images and Ideals in Literature and Society. New York: Continuum International Publishing Group, 1987.

Deepika, Srivastava. Charles Dickens: A Perspective Sarup \& Sons New Delhi 2001

Gissing, George. A Critical Study: Charles Dickens Elibron Classics series. Adamant Media Corporation. London. 2005

Makati, Pamela. A Critical Study of Charles Dickens' Representation of The Socially Disadvantaged University of Fort Hare 2008

Pakditawan, Sirinya. Childhood in Victorian England and Charles Dickens' Novel "Oliverb Twist" GRIN Verlag 2002 Norderstedt Germany p.4

Pykett, Lynn Charles Dickens Palgrave New York 2002

Reed, John R. The Gentleman in the White Waistcoat: Dickens and Metonymy Wayne State University Style: Volume 39, No.4, Winter 2005

Paris, Bernard J. Imagines Human Beings A Psychological Approach to Character and Conflict in Literature. New York University Press. New York. 1997

Srivastava, Deepika. Charles Dickens: A Perspective Sarup \& Sons New Delhi 2001 lan Press Ltd., 1999. 
Thomas Taaffe Education of the Heart Cross Currents, Fall 95, Vol. 45 Issue 3, p.380

Wilson, Ben. The Making of Victorian Values: Decency and Dissent in Britain, 1789 - 1837. New York: The Penguin Press, 2007

\section{Internet Resources}

Quote from Aristotle http://www.quoteswave.com/picture-quotes/240986

Child Labor Information http://www.spartacus.schoolnet.co.uk

Treatise on Food and Diet with Observations on the Dietetically Regime

www.bmj.com/content/337/bmj.a2722.full

London's Population in 1800s http://www.oldbaileyonline.org/static/London-life19th.jsp

Dickens and religion http://dickens.ucsc.edu/resources/faq/religion.html 